This item was submitted to Loughborough's Research Repository by the author.

Items in Figshare are protected by copyright, with all rights reserved, unless otherwise indicated.

\title{
Identifying trends in the use of domestic appliances from household electricity consumption measurements
}

PLEASE CITE THE PUBLISHED VERSION

PUBLISHER

(C) Elsevier

VERSION

AM (Accepted Manuscript)

LICENCE

CC BY-NC-ND 4.0

\section{REPOSITORY RECORD}

Firth, Steven K., Kevin J. Lomas, A.J. Wright, and R. Wall. 2019. "Identifying Trends in the Use of Domestic Appliances from Household Electricity Consumption Measurements". figshare.

https://hdl.handle.net/2134/5286. 
This item was submitted to Loughborough's Institutional Repository (https://dspace.lboro.ac.uk/) by the author and is made available under the following Creative Commons Licence conditions.

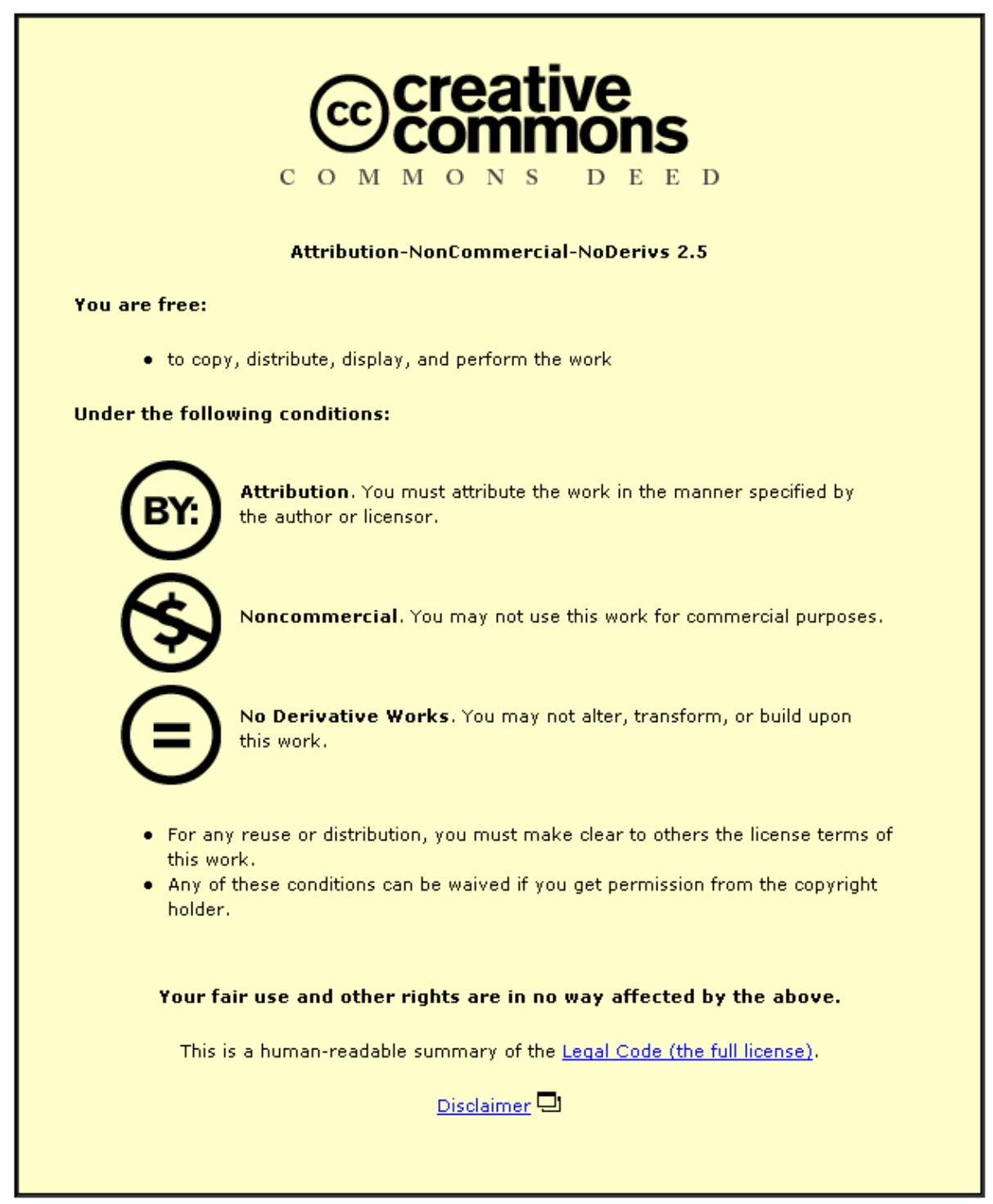

For the full text of this licence, please go to: http://creativecommons.org/licenses/by-nc-nd/2.5/ 


\title{
Identifying trends in the use of domestic appliances from household electricity consumption measurements
}

\author{
S.K. Firth *, K.J. Lomas, A.J. Wright and R. Wall \\ The Institute of Energy and Sustainable Development, De Montfort University, Leicester, UK \\ * Corresponding author. Tel: +44 (0) 116257 7966; fax: +44 (0)116 2577981. \\ E-mail address: sfirth@dmu.ac.uk (S. Firth).
}

\begin{abstract}
Results are presented from a monitoring study of the electricity consumption of a sample of UK domestic buildings. Five-minutely average whole house power consumption was recorded for seventy-two dwellings at five sites over a two-year monitoring period. The mean annual electricity consumption for the households increased significantly by $4.5 \%(t=1.9 ; \mathrm{p}<0.05$, one-tailed) from the first to the second year of monitoring. New techniques are developed which estimate the electricity consumption of different appliance groups, based on analysis of the five-minutely monitored data. The overall increase in electricity consumption is attributed to a $10.2 \%$ increase in the consumption of 'standby' appliances (such as televisions and consumer electronics) and a 4.7\% increase in the consumption of 'active' appliance (such as lighting, kettles and electric showers). The consumption of different energy user groups (low, medium and high) is also investigated and low and high users are identified as contributing to the overall increase in consumption. The need for further investigation, such as quantitative and qualitative studies, to improve understanding in domestic electricity consumption is discussed.
\end{abstract}

Keywords: Domestic, household, energy, electricity, monitoring, standby power

\begin{tabular}{|ll|}
\hline Nomenclature & $\begin{array}{l}\text { Number of } \mathrm{P}_{1-4} \text { values in the 01:00 to 04:00 } \\
\mathrm{n}_{1-4}\end{array}$ \\
$\mathrm{P}_{1-4}$ & $\begin{array}{l}\text { Five-minutely average electric power } \\
\text { consumption of the household recorded } \\
\text { between 01:00 and 04:00 (W) }\end{array}$ \\
$\bar{P}_{\text {AСтIVE }}$ & $\begin{array}{l}\text { Daily average electric power consumption } \\
\text { of the active appliances and the standby } \\
\text { appliances in use (W) }\end{array}$ \\
\hline
\end{tabular}




\begin{tabular}{|ll|}
\hline $\bar{P}_{\text {COLD }}$ & $\begin{array}{l}\text { Daily average electric power consumption } \\
\text { of the cold appliances (W) }\end{array}$ \\
& $\begin{array}{l}\text { Five-minutely average electric power } \\
\text { consumption of the continuous appliances } \\
\text { (W) }\end{array}$ \\
& $\begin{array}{l}\text { Five-minutely average electric power } \\
\text { exported to the mains grid (W) }\end{array}$ \\
& $\begin{array}{l}\text { Five-minutely average electric power } \\
\text { consumption of the continuous appliances } \\
\text { and standby appliances in standby mode }\end{array}$ \\
& $\begin{array}{l}\text { (W) } \\
\text { Daily average electric power consumption } \\
\text { of the continuous appliances and standby } \\
\text { appliances in standby mode (W) }\end{array}$ \\
$\bar{P}_{\text {C\&S }}$ & $\begin{array}{l}\text { Five-minutely average electric power } \\
\text { imported from the mains grid (W) }\end{array}$ \\
$\mathrm{P}_{\text {IMPORT }}$ & $\begin{array}{l}\text { Five-minutely average electric power } \\
\text { consumption of the household (W) }\end{array}$ \\
$\mathrm{P}_{\text {TOTAL }}$ & $\begin{array}{l}\text { Daily average total electric power } \\
\text { consumption (W) }\end{array}$ \\
$\bar{P}_{\text {TOTAL }}$ & $\begin{array}{l}\text { Five-minutely average electric power } \\
\text { generation by the photovoltaic system (W) }\end{array}$ \\
$\mathrm{P}_{\text {PV }}$ & $\begin{array}{l}\text { Five-minutely average electric power } \\
\text { consumption of the standby appliances in } \\
\text { standby mode (W) }\end{array}$ \\
$\mathrm{P}_{\text {STANDBY MODE }}$ & \\
&
\end{tabular}

\section{Introduction}

Electricity consumption in domestic buildings is determined by two main factors: the type and number of electrical appliances in the property; and the use of these appliances by the occupants of the building. In houses with similar built forms there can be a wide range of different appliances in use and these appliances will have a range of different power consumptions. Occupants influence the electricity use of a dwelling both by their purchase of electrical appliances and through their use of these appliances. The variation in the type of electrical appliances present and the occupant's semi-random use of these makes domestic electricity consumption difficult to predict with accuracy, particularly at short time steps such as an hour or less.

However, it is recognised that a sound understanding of domestic electricity consumption is required for the design and implementation of energy efficiency measures [1] and on-site electricity generation [2].

The UK Government’s Climate Change Bill in 2007 sets a legally binding target of a 60\% reduction in national $\mathrm{CO}_{2}$ emissions by 2050 compared to 1990 levels [3]. Electricity consumption from housing represented 29\% of total UK electricity consumption in 2005 [4]. Schemes to reduce domestic electricity consumption include technical measures, such as low energy lighting and the energy labelling of appliances 
[5], and measures designed to influence the occupants' behaviour, such smart metering [6]. The main aim of smart metering is to encourage consumers to use less electricity through being better informed about their consumption patterns. The consumption of carbon-intensive mains electricity can also be avoided thorough the use of on-site micro-generation systems which produce low-carbon electricity at the dwelling itself. The UK Government’s Low Carbon Buildings Programme provides grants to install micro-generation systems such as solar PV, micro-wind turbines and combined heat and power units [7]. However the penetration of low energy appliances, smart metering and micro-generation is currently limited and the average household domestic electricity consumption has increased by 1.2\% between 2000 and 2004 [8]. This increase has occurred at a time when the efficiency of new household electrical goods, such as refrigeration and washing appliances, has improved considerably [9]. The reasons why this increase in overall domestic electricity consumption has occurred need to be clearly understood in order to develop future policy to reduce consumption from the UK housing stock.

National statistics provide annual totals of domestic electricity consumption, often as average values. UK Government delivered energy statistics show that the average UK household consumed 4,068 kWh of electricity in 2004 [10]. The English House Condition Survey (EHCS) in 2001 collected metering data on 7,370 households in England with an average annual electricity consumption of 5,282 kWh [11]. These figures include the electricity used for hot water and space heating as well as the appliance consumption. The EHCS survey demonstrated how electricity use varies with the floor area of dwellings, household income and many other factors. However such annual values do not provide sufficient detail for planning effective interventions such as the replacement of appliances or promoting behavioural change. More detailed studies with smaller sample sizes can provide greater insight to electricity consumption trends. For example, a 2007 longitudinal study of 15 UK dwellings found a 31.6\% rise in electricity consumption over a fifteen year period and identified the largest increases in the households with high annual consumptions [12].

Models have been used to predict the consumption of groups of appliances. The DECADE project provided national estimates for the consumption of groups of appliances based on ownership statistics and the average consumptions of the appliance stock [13]. For example, the breakdown of the national electricity consumption by appliance group in 2003 gives: lighting 20\%; refrigeration appliances 18\%; cooking appliances 17\%; brown appliances (such as televisions, computers and communication devices) 21\%; and wet 
appliances (such as washing machines, tumble dryers and dishwashers) 14\%. At the individual household level the BREDEM model predicts monthly or annual total electricity use using algorithms based on total floor area of the dwelling and number of occupants [14]. No account of the occupant behaviour is used in BREDEM and the predictions are only intended to give an average household figure [15]. Load models have also been developed to predict individual household electricity consumption at one minute or half hour intervals [16], [17]. These models make predictions of energy consumption patterns for a typical household and do not reflect the large inter-dwelling variation that occurs in practice.

Monitoring studies can provide current data on individual household electricity consumption and such studies generally take two approaches. Monitoring equipment can be used to record the consumption of individual appliances or of collections of appliances. An example of this approach is a study by the Swedish Energy Agency which recorded appliance consumption data for 400 households [18]. This provided accurate consumption data on individual appliances and the results are of sufficient detail to make energy efficiency recommendations. The second approach is to monitor the whole house electricity consumption at a high resolution. A demand side management study in 1999 recorded one-minutely electricity load profiles for 30 homes over periods of one to four weeks [19]. The recorded loads clearly show the effects of different appliances on consumption levels. Similar monitoring studies in the non-domestic building sector have also been undertaken which identify consumption patterns based on whole building electricity measurements [20].

This work was undertaken as a part of the UK Carbon Reduction in Buildings (CaRB) project [21]. It investigates current trends in electricity consumption in UK dwellings through the analysis of recent field measurements. Novel analysis procedures have been developed to improve the understanding of domestic electricity consumption based on high-resolution five-minutely measurements of household electricity consumption. Seventy-two UK households are studied and the energy consumption of appliances with different consumption patterns is identified. The aim of this work is to improve the current understanding of electricity consumption in UK domestic buildings and to identify the trends in consumption of different appliance groups.

\section{Household electrical appliance categories}

The electricity consumption of a household is determined by the electric power consumed by each appliance and the amount of time each appliance is in use. In this study four categories of appliances have 
been identified according to their pattern of use: continuous appliances; standby appliances; cold appliances; and active appliances (Table 1). Continuous appliances, such as clocks and burglar alarms, draw a continuous constant amount of power. Standby appliances, in particular consumer electronic equipment such as televisions and set-top boxes, have three basic modes of operation: in use; on standby; or switched off. Standby use occurs when an appliance is not in use but is still consuming power [22]. Appliances can be on standby even when they appear to be switched off and the only certain way to prevent them drawing power is to disconnect their power supply. Cold appliances, such as fridges and freezers, are in continuous use however they do not draw a constant amount of power. Instead their power consumption cycles between zero and a set power level which is under thermostatic control. Active appliances are those which are actively switched on or off by the householders and are clearly either in use or not in use. Active appliances have no standby mode and when switched off their power consumption is zero. Examples of active appliances include lights, kettles and electric showers.

\section{Household power consumption measurements}

This study investigates the electricity consumption of seventy-two UK households (Table 2). The dwellings were part of a wider study researching photovoltaic (PV) systems installed on UK domestic buildings [27]. The households were clustered in five sites with each site containing between ten and twenty two properties. Four of the sites were social housing and the dwellings all had gas central heating. The built forms were detached houses, terrace bungalows, two-storey blocks and flats (e.g. Figure 1). The electricity consumption of each dwelling was monitored for a two year period. Five-minutely average values of PV system electricity generation, import of electricity from the grid and export of electricity to the grid were recorded by current and voltage sensors and pulsed output meters. Data was collected using loggers installed in a number of the homes and was downloaded on a regular basis via the public telephone network. The data loggers had a constant power draw of $10 \mathrm{~W}$ and this power consumption was subtracted from the recorded household power consumption where necessary. The monitoring systems were funded by the UK Department of Trade and Industry under the PV Domestic Field Trial programme [28] and the energy consultants for the sites were Energy for Sustainable Development Ltd.

For each five minute recording interval, average values of PV system electricity generation, import of electricity from the grid and export of electricity to the grid were recorded. The five-minutely average total 
electrical power consumption (defined as the average power drawn by all the electrical appliances in the home during the five minute period) was derived from the measurements using the following equation:

$$
P_{\text {TOTAL }}=P_{P V}+P_{\text {IMPORT }}-P_{\text {EXPORT }}
$$

\section{High-resolution data analysis}

\subsection{Domestic electricity consumption patterns}

For each dwelling, the electricity consumption recorded over the two year period contained over 200,000 individual data values. Standard spreadsheet software is not sufficient to analysis such data as there is, typically, a limit on the number of data entry rows allowable and a limit on the number of data points on graphs. Therefore specialised software, the Interactive Data Language (IDL) software package, was used [29]. IDL is an array-based data processing package and can work with large datasets easily. A series of routines were developed in the IDL Development Environment to import, screen, store, analyse and display the monitored data (Figure 2). These generic routines form part of an IDL application which can analyse timeseries energy consumption data from any source and at any recording interval (such as one-second intervals, five-minute intervals or half-hour intervals).

The value of using high-resolution data in studying domestic electricity consumption patterns has been discussed elsewhere [30]. Most importantly, such data allows detailed insights which enable the categories of appliances (see Table 1) to be inferred. As an example, Figure 3 shows the five-minutely electrical power consumption for a single house versus the time of day (00:00, 00:05 etc.). This figure shows over 200,000 five-minutely values recorded in the two-year monitoring period. Between midnight and 06:00 the total power consumption was always relatively low with an average value of $228 \mathrm{~W}$. There were some high power consumptions (over $1000 \mathrm{~W}$ ) in this time period and further investigation showed that these occurred only on three separate occasions when many of the appliances remained in use overnight. At around 06:00 the occupants began to actively use the appliances in the home and higher power consumptions were recorded. This continued until around 21:00 when power consumption levels started to return to their low, night-time levels. For each five-minute interval the average total power consumption is shown by the grey line on the figure. This provides an indication of the daily pattern of consumption in the dwelling. It is clear however that this average profile is not at all representative of actual recorded data and in particular does not portray the very high, short term power demands that occur. 
From a more detailed inspection of the data, the operation of equipment in each of the appliance categories defined in Table 1 can be observed. Taking as an example the total power consumption values recorded at one house over a single day, the five-minutely average total power consumption show a typical residential electricity use pattern (Figure 4). During the early morning from 02:00 to 08:00 there was a constant cyclic pattern of power consumption between around $50 \mathrm{~W}$ and $180 \mathrm{~W}$. The minimum power consumption of $50 \mathrm{~W}$ represents the power consumption of the continuously on appliances and the appliances in standby mode. The repeated increase up to $180 \mathrm{~W}$ was caused by the power consumption of the cold appliances and this pattern can be seen continuing through the day. After 08:00 the power consumption rose as other appliances begin to be used in the household. There were several high peaks above $1000 \mathrm{~W}$ which were caused by active appliances with high power consumption such as a kettle. After 17:00 there was a step-change increase of around $100 \mathrm{~W}$ in the power consumption values compared to the early morning which was probably caused by the use of active appliances such as lights and the switching on of appliances previously in standby mode such televisions and other consumer electronics.

Because the monitored data records the total power consumption of the dwellings, it was difficult to distinguish the contribution of individual appliances. The analysis techniques presented here infer, from the five-minutely data, the electricity consumption of three appliance consumption groups (based on the appliance categories in Table 1): the continuous appliances and standby appliances in standby mode; the cold appliances; and the active appliances including the standby appliances in use. It is worth noting here that the four categories give in Table 1 were chosen pragmatically for the purpose of categorising the features of domestic electricity use. The categories are not intended to offer a basis for classifying electrical appliances. A taxonomy of appliances is however being developed as part of the CaRB project [31].

\subsection{Continuous and standby energy consumption}

The first appliance consumption 'group' identified in the data is the combined total of the power consumption of continuous appliances and appliances left in standby-mode. This power consumption was defined in this work as the continuous and standby power (C\&S) and is given as:

$$
P_{\text {C\&S }}=\sum P_{\text {CONTINUOUS }}+\sum P_{\text {STANDBY }_{-} \text {MODE }}
$$

The power consumption of the continuous appliances and appliances left in standby-mode can be observed from the minimum power consumption of the household in each day. As shown in Figure 4 it is assumed that 
when this minimum power consumption occurred, there was no consumption from cold appliances, standby appliances in use or active appliances. Thus for each day the continuous and standby power consumption $\left(\bar{P}_{C \& S}\right)$ is given by:

$\bar{P}_{C \& S}=\operatorname{minimum}\left(P_{\text {TOTAL }}\right)$

Monthly average continuous and standby power is shown for three sample houses at Site 1 in Figure 5.

House A is an example of a household with a high continuous and standby power consumption of around 190 W. At House B there was a decrease in continuous and standby power between July and October 2003 from around $180 \mathrm{~W}$ to $50 \mathrm{~W}$. This would be caused by a significant change in the presence or use of appliances in the home. House $\mathrm{C}$ had a low continuous and standby power consumption of around $30 \mathrm{~W}$ throughout the monitoring period. For each house, the daily continuous and standby electricity consumption was estimated by assuming that the values of continuous and standby power consumption remain constant throughout each day. For example a dwelling with a daily continuous and standby power of $50 \mathrm{~W}$ is calculated to have daily continuous and standby electricity consumption of $1.2 \mathrm{kWh}$.

\subsection{Cold appliance energy consumption}

The power consumption of cold appliances such as fridges was identified in the monitored data from the values recorded between 01:00 and 04:00. At this time it is assumed that there is little or no use of active appliances (as it is night time and the occupants are asleep) and power consumption is mainly caused by continuous and standby power and cold appliances. A plot of early morning power consumption against time of day for two sample dwelling illustrates the nature of cold appliance power consumption (Figure 6). House A shows a cycling pattern from around $25 \mathrm{~W}$ to $175 \mathrm{~W}$ which occurred approximately every hour. The minimum value of $25 \mathrm{~W}$ was the continuous and standby power consumption and the increase to $175 \mathrm{~W}$ was caused by the power consumption (150 W) of the cold appliances. House B shows a similar cycle with power consumption varying between $0 \mathrm{~W}$ and $90 \mathrm{~W}$ which repeated approximately every 40 minutes.

The daily average power consumption of cold appliances was calculated as the average power recorded between 01:00 and 04:00 minus the daily continuous and standby power consumption (as defined by Equation 3). There was occasional use of other appliances in the early morning some of which may have high power consumptions (such as kettles or security lights). These can cause an overestimation of the power consumption attributed to the cold appliances. To correct for this, any power consumption greater than $400 \mathrm{~W}$ 
above the calculated daily continuous and standby power was ignored. The level of $400 \mathrm{~W}$ was chosen as it is unlikely that a combination of cold appliances would have total power consumption above this value. The daily cold appliance average power consumption is given by:

$\bar{P}_{C O L D}=\frac{1}{n_{1-4}} \sum P_{1-4}-\bar{P}_{C \& S}$

The average daily electricity consumption of the cold appliances is calculated by assuming that $\bar{P}_{C O L D}$ remains constant throughout the day. It is recognised that his approach might lead to a slight underestimate of the cold appliance energy use because the cycling could be more rapid during the day when the door of the appliance is opened and closed and the surrounding air temperature is higher. The latter effect may be less pronounced if the cold appliance is located in a poorly insulated space such as a garage. Previous work has shown that cold appliance energy use may be around $5 \%$ to $10 \%$ less in the early morning compared to the whole day [26] but no attempt to correct for this has been made in this work.

\subsection{Active appliance energy consumption}

The remaining portion of household electricity consumption is accounted for by the active appliances and standby appliances in use. These appliances are difficult to detect individually, using the simple approach to analysis adopted here, as there can be a great variety of different appliances, each with different power demands, and there is often no discernable pattern of use. The daily average power consumption of the active appliances and standby appliance in use $\left(\bar{P}_{\text {ACTIVE }}\right)$ is given by Equation 5 . The daily average power consumption is used to calculate annual consumption totals for each household.

$$
\bar{P}_{\text {ACTIVE }}=\bar{P}_{\text {TOTAL }}-\bar{P}_{C \& S}-\bar{P}_{\text {COLD }}
$$

\section{Analysis of electricity consumption trends}

\subsection{Annual results for the first year of monitoring}

The annual electricity consumption totals for each consumption group were calculated for the seventy-two monitored dwellings. The results for the first year of monitoring are shown in Figure 7 where each vertical bar represents the results for an individual dwelling. The height of the bars gives the annual total consumption (the electricity consumption of all appliances) and the bars are divided to show the contribution of the three groups: continuous and standby, cold and active. The results are arranged in the order of the annual total consumption and the location of each dwelling is shown by the site number. It is evident that there is a large 
variation in consumption across the dwellings. For example, the lowest annual total electricity consumption was $902 \mathrm{kWh}$, consisting of a continuous and standby consumption of $104 \mathrm{kWh}$, a cold appliance consumption of $236 \mathrm{kWh}$ and an active appliance consumption of $562 \mathrm{kWh}$. The highest annual total electricity consumption was $7743 \mathrm{kWh}$, with a continuous and standby consumption of $1993 \mathrm{kWh}$, a cold appliance consumption of $481 \mathrm{kWh}$ and an active appliance consumption of $5269 \mathrm{kWh}$. There appears to be no correlation between the dwellings of a particular site and their electricity consumption. The dwellings were split into three energy user groups according to their annual total consumption in the first year of monitoring. The twenty-four dwellings with the lowest annual total consumption (902 kWh to $2160 \mathrm{kWh}$ ) were assigned to the low energy group, the middle twenty-four ( $2174 \mathrm{kWh}$ to $3247 \mathrm{kWh}$ ) to the medium energy group and the highest twenty-four (3273 kWh to $7743 \mathrm{kWh}$ ) to the high energy group.

For all dwellings in the first year of monitoring the average total electricity consumption was $3100 \mathrm{kWh}$ (Table 3). This is lower than the UK Government estimate of average annual electricity consumption of all UK dwellings (4068 kWh in 2004) which reflects perhaps the fact that the monitored dwellings were mostly social housing and so did not contain all types of UK housing (such as large, detached houses). For all the dwellings, the continuous and standby consumption represented $19 \%$ of the total consumption, the cold appliance consumption $20 \%$ and the active appliance consumption $61 \%$. The proportion of cold appliance consumption matches well with the results from the DECADE project [13] (which estimated the proportion of cold appliance consumption at $18 \%$ for 2003). The consumption figures can also be expressed in terms of equivalent continuous power. For example, the dwellings' average annual total consumption of $3100 \mathrm{kWh}$ has an equivalent continuous power of $354 \mathrm{~W}$. The equivalent continuous power is useful when considering the plausibility of the results, in particular for the continuous and standby consumption. The equivalent continuous power for the average continuous and standby consumption was $69 \mathrm{~W}$ (equivalent to the combined standby power of several appliances such as televisions, stereos, set-top boxes, desktop computers and cold appliances as given in Table 1). This can be compared to previous work by the EURECO project which gives an average equivalent continuous power of $50 \mathrm{~W}$ for $400 \mathrm{EU}$ houses monitored in 2000 [25].

The annual results show that continuous and standby and active appliance consumption were greater in the high energy group than the low energy group (Table 3). Cold appliance consumption was similar for the low and medium energy groups and higher in the high energy groups. These relationships were investigated by 
plotting the continuous and standby, cold appliance and active appliance annual consumptions against annual total consumption for the first year of monitoring (Figure 8). Linear regression lines were fitted to the data points and, although they do not capture the variation in the results, they do give an indication of the overall trends. Continuous and standby, cold appliance and active appliance consumption all appear to increase as total consumption increases, although cold appliance consumption increases only marginally. This is to be expected as it is likely that dwellings will not have more than one or two refrigeration appliances irrespective of occupant numbers, ownership of other appliances or consumption patterns. Both continuous and standby consumption and active appliance consumption increased greatly with the total consumption. In households with low annual total consumption the continuous and standby consumption is lower than the cold appliance consumption. The regression lines in Figure 8 show that around an annual total consumption of $3000 \mathrm{kWh}$ the continuous and standby consumption becomes, on average, larger than the cold appliance consumption.

\subsection{Analysis of electricity consumption trends for all households}

The results for all dwellings from the first year of monitoring (Year 1) to the second year of monitoring (Year 2) were compared to investigate the trends over time (Table 4). The mean, standard deviation and range (minimum to maximum) were calculated for the total consumption, continuous and standby consumption, cold appliance consumption and active appliance consumption. There was an increase from Year 1 to Year 2 in the average total consumption from $3100 \mathrm{kWh}$ to $3241 \mathrm{kWh}$. On average, continuous and standby consumption increased from $601 \mathrm{kWh}$ to $662 \mathrm{kWh}$ and active consumption from $1879 \mathrm{kWh}$ to $1968 \mathrm{kWh}$. The average cold appliance consumption decreased slightly from $620 \mathrm{kWh}$ to $610 \mathrm{kWh}$. For each set of results paired sample t-tests were applied to the Year 1 and Year 2 values to test the significance of any change.

Total consumption increased on average by $141 \mathrm{kWh}$, an increase of $4.5 \%$. The increase in total consumption was caused by the overall increase in continuous and standby consumption of $61 \mathrm{kWh}(10.2 \%)$ and active consumption of $89 \mathrm{kWh}$ (4.7\%). The consumption of cold appliances decreased slightly overall by $9 \mathrm{kWh}(-1.5 \%)$ during the monitoring period. The ownership of cold appliances may have saturated in the households (most households are unlikely to purchase additional cold appliances) and the decrease may be caused by the replacement of cold appliances with higher efficiency models. The t-tests showed that the continuous and standby annual increase was significant at the $\mathrm{p}<0.05$ level if the two-tailed $\mathrm{p}$ value is used. 
However if the one-tailed p value is used (reflecting the hypothesis that, based on current trends, energy consumption would increase from Year 1 to Year 2) then the increases in total consumption and active consumption can also be considered significant at the 0.05 level.

\subsection{Analysis of electricity consumption trends by energy group}

The trends in annual consumption totals are investigated further by considering results for the low, medium and high energy groups separately. For each group descriptive statistics and t-tests were calculated for the total, continuous and standby, cold appliance and active appliance consumption categories for the first and second year of monitoring (Table 5). There were clear differences between the low, medium and high energy groups. Total average consumption increased overall from $1770 \mathrm{kWh}$ to $1964 \mathrm{kWh}(11.0 \%)$ for the low energy group and from $4841 \mathrm{kWh}$ to $5088 \mathrm{kWh}$ (5.1\%) for the high energy group. For the medium energy group the total household consumption decreased slightly over the monitoring period from $2689 \mathrm{kWh}$ to 2670 $\mathrm{kWh}(-0.7 \%)$. The increase for the low energy group was significant at the $\mathrm{p}<0.05$ level using the two-tailed $\mathrm{p}$ value. The increase observed in the low and high energy groups was largely caused by increases in the continuous and standby consumption and active appliance consumption. For the continuous and standby consumption there was a rise from $297 \mathrm{kWh}$ to $375 \mathrm{kWh}$ (26.3\%) in the low energy group and a rise from $1104 \mathrm{kWh}$ to $1222 \mathrm{kWh}(10.7 \%)$ in the high energy group. The active appliance consumption increased from $938 \mathrm{kWh}$ to $1069 \mathrm{kWh}$ (13.9\%) for the low energy group (significant at the $\mathrm{p}<0.05$ level using a two-tailed test) and from $2990 \mathrm{kWh}$ to $3114 \mathrm{kWh}$ (4.2\%) for the high energy group. The decrease in total consumption in the medium energy group was due to a decrease in continuous and standby consumption, from $402 \mathrm{kWh}$ to $389 \mathrm{kWh}$ (-3.1\%), and in cold appliance consumption, from $577 \mathrm{kWh}$ to $559 \mathrm{kWh}(-3.3 \%)$.

\section{Discussion}

This study has focussed on a relatively small number of dwellings (72), all of which were occupied from one to three years before monitoring began and the majority of which were modestly-sized social housing. It would not therefore be wise to draw sweeping conclusions from the analysis or to make strong statements concerning policies to reduce the $\mathrm{CO}_{2}$ emissions in the UK housing stock. The study does however support the observations of others that there is a growing demand for electricity and that the consumption of appliances that are either continuously on or in standby-mode (continuous and standby consumption) is an area that might usefully be addressed to reduce the UK's $\mathrm{CO}_{2}$ emissions. This is demonstrated firstly because 
the continuous and standby energy consumed, of which the standby energy serves no useful function, is relatively high (around 19\% of the total) for the group of dwellings studied and secondly because it appears to be an area in which consumption is growing (by $10.2 \%$ on average over just two years in the study).

The total increase in energy consumption of the 72 dwellings was $4.5 \%$ in just two years. This is rather higher than reported elsewhere, e.g. an increase of $1.2 \%$ for households for the nation as a whole between 2001 and 2004 [8]. The difference could well be because the houses are relatively new and the occupants were in the process of furnishing their new homes with new or replacement appliances. It would be constructive to continue the monitoring to assess whether the observed trend continues. Elsewhere within the CaRB project a longitudinal study is being set up which should enable the long term trends in domestic electrical use to be charted for a sample of houses that is more statistically representative of UK households [32].

This study made use of the monitored whole house electricity consumption data from which trends in the energy consumption groups could be inferred. It is possible that with more sophisticated analysis, perhaps linked to limited individual appliance monitoring, much greater insight into individual active appliance usage (frequency and duration) could be gained; this is being exploited in the CaRB project. From the results available here we can hypothesise that the increase in total consumption, primarily in continuous and standby energy use but also in active appliance use, could be due to either: the presence in the dwellings of more appliances with standby and active modes; the presence of more appliances that are continuously on; the replacement of older products with newer ones that consume more energy in one or other of these modes; or the more frequent use of standby and active appliances. Subjectively one can imagine that any or all of these could be true: many households are purchasing poorly designed IT equipment (modems, printers, scanners etc.) that are always on and older CRT TVs are being replaced with larger flat screen (LCD or plasma) TVs which incorporate a standby mode and consume more power. Only by linking measured data, such as that used in this paper, with quantitative surveys of appliance ownership can greater insight can be gained and only by linking such studies with qualitative social science research to understand the motivations and drivers for appliance usage, can policies for reducing consumption can be reliably framed. Work of the latter type, which focuses on lighting energy use, has already been started in the CaRB project and will be extended to cover other end uses. A further study aims to collect high frequency data of individual appliance consumption 
in around 40 homes which, combined with measurements of whole house consumption, will build on the techniques described in this paper.

\section{Conclusions}

A longitudinal study of electricity consumption in a sample of UK domestic buildings has been carried out which identifies the trends in their appliance energy use. Whole house electric power consumption measurements, recorded on a five-minutely basis for 72 dwellings over a two-year monitoring period, has been used to demonstrate a series of new analysis techniques to improve understanding of domestic electricity use. The techniques distinguish the consumption of three appliance groups: continuous appliances and standby appliances in standby mode; cold appliances; and active appliances including standby appliances in use. Key conclusions are:

- There is great variation in the annual electricity consumption of the dwellings. Even those dwellings on the same site and with similar built form have notably different annual electricity consumptions. This suggests that built form is not a strong determining factor in household electricity use and instead factors such as number of occupants, number and type of appliances, and occupancy patterns may be more relevant.

- Annual electricity consumption of the dwellings increased from the first to the second year of monitoring, from $3100 \mathrm{kWh}$ to $3241 \mathrm{kWh}$ (4.5\%). This result was significant at the $\mathrm{p}<0.05$ level (using the one-tailed p value) and is illustrative of the trend in rising electricity consumption of the UK housing stock. The contributing factors to this increase were shown to be increases in consumption from continuous, standby and active appliances. Continuous and standby electricity consumption (from continuous appliances and standby appliances in standby mode) increased on average by $10.2 \%$ (from $601 \mathrm{kWh}$ to $662 \mathrm{kWh}$ ) and active appliance consumption by $4.7 \%$ (from $1879 \mathrm{kWh}$ to $1968 \mathrm{kWh}$ ). Cold appliances were shown not to have contributed to the overall increase in household electricity consumption: on average a 1.5\% decrease (from $620 \mathrm{kWh}$ to $610 \mathrm{kWh}$ ) was observed.

- The low and high energy users were responsible for the overall increase in electricity consumption in the monitored dwellings. The total annual consumption of the low energy group increased by $11 \%$ (from 1770 $\mathrm{kWh}$ to $1964 \mathrm{kWh}$ ) over the monitoring period and the high energy group by 5.1\% (from $4841 \mathrm{kWh}$ to $5088 \mathrm{kWh}$ ). The medium energy group reduced consumption slightly by $0.7 \%$ (from $2689 \mathrm{kWh}$ to 2670 
$\mathrm{kWh}$ ) during the monitoring period. It was the increase in continuous and standby consumption and active consumption which caused the rise in total consumption in the low and high energy users.

This work has demonstrated the role of monitoring in understanding the trends in electricity consumption in dwellings and also established the need for qualitative and quantitative studies to explore the factors (technical, socio-demographic and behavioural) which influence these trends. This work is continuing within the CaRB project and will build on the findings presented in this paper.

\section{Acknowledgements}

This work forms part of Carbon Reduction in Buildings (CaRB) Consortium. CaRB has 5 UK partners: De Montfort University, University College London, The University of Reading, The University of Manchester and The University of Sheffield. CaRB is supported by the Carbon Vision initiative which is jointly funded by the Carbon Trust and Engineering and Physical Sciences Research Council, with additional support from the Economic and Social Research Council and Natural Environment Research Council. The partners are assisted by a steering panel of representatives from UK industry and government. See http://www.carb.org.uk for further details.

The specific assistance of Energy for Sustainable Development Ltd is gratefully acknowledged.

\section{References}

[1] Energy Saving Trust. The rise of the machines: a review of energy using products in the home from the 1970s to today. Report CO126. Energy Savings Trust, www.est.org.uk, 2006

[2] A.S. Bahaj, L. Myers, P.A.B. James. Urban energy generation: Influence of micro-wind turbine output on electricity consumption in buildings, Energy and Buildings 39 (2007) 154-165

[3] Department of Food and Rural Affairs. Climate Change Bill, www.defra.gov.uk, 2007

[4] Department of Trade and Industry. Digest of UK energy statistics (DUKES) 06, www.dti.gov.uk, 2006

[5] BNC07: Domestic cold appliance EC Energy Label revision, Briefing Note, Market Transformation Programme, www.mtprog.com, 2006

[6] Information note R/43, £9.75 million trial to improve energy information for customers, The Office of Gas and Electricity Markets, UK, www.ofgem.gov.uk, 2006

[7] Low Carbon Building Programme, www.lowcarbonbuildings.org.uk 
[8] Energy consumption tables: domestic energy consumption, Table 3.1, Department of Trade and Industry, UK, http://www.dti.gov.uk/energy/statistics/publications/ecuk/domestic/page18071.html [accessed February 2007]

[9] F. Stöckle. Trends of Major Domestic Appliances Sales in the Various Phases of Energy Efficiency Legislation in Europe. Energy Efficiency in Domestic Appliances and Lighting (EEDAL) conference, London, June 2006

[10] Energy Trends December 2005. Department of Trade and Industry, www.dti.gov.uk, 2005

[11] Energy use in homes: a series of reports on domestic energy use in England: fuel consumption. Building Research Establishment, Garston, Watford, UK, 2005

[12] A. Summerfield, R. Lowe, H. Bruhns, J. Caeiro, J. P. Steadman, T. Oreszczyn, Milton Keynes Energy Park revisited: Changes in internal temperatures and energy usage, Energy and Buildings 39 (2007) 783791

[13] B. Boardman, D. Favis-Mortlock, M. Hinnells, K. Lane, G. Milne, J. Palmer, E. Small, V. Strang, J. Wade. DECADE: Domestic equipment and carbon dioxide emissions, second report, Environmental Change Institute, University of Oxford, 1995

[14] B. Anderson, P. Chapman, N. Cutland, C. Dickson, S. Doran, G. Henderson, J. Henderson, P. Iles, L. Kosmina, L. Shorrock. BREDEM-8: model description 2001 update. Building Research Establishment, Garston, Watford, UK, 2002

[15] C.M. Dickson, J.E. Dunster, S.Z. Lafferty and L.D. Shorrock. BREDEM: Testing monthly and seasonal versions against measurements and against detailed simulation models. Building Services Engineering Research and Technology, Vol 17 No. 3, 1996

[16] M. Stokes. Removing barriers to embedded generation: a fine-grained load model to support low voltage network performance analysis. PhD thesis, De Montfort University, 2005

[17] R. Yao, K. Steemers. A method of formulating energy load profile for domestic building in the UK, Energy and Buildings 37 (2005) 663-671

[18] P. Bennich, A. Persson. Methodology and first results from end-use metering in 400 Swedish households. Energy Efficiency in Domestic Appliances and Lighting (EEDAL) conference, London, June 2006 
[19] M. Newborough and P. Augood. Demand-side management opportunities for the UK domestic sector, IEEE Proceedings - Generation, Transmission and Distribution, Vol. 146, No. 3, 1999

[20] G. Stuart P. Fleming, V. Ferreira, P. Harris. Rapid analysis of time series data to identify changes in electricity consumption patterns in UK secondary schools, Building and Environment 42 (2007) 15681580

[21] Carbon Reduction in Buildings (CaRB), www.carb.org.uk

[22] D. Cogan, M. Camilleri, N. Isaacs, L. French. National Database of Household Appliances Understanding Baseload and Standby Power Use. Energy Efficiency in Domestic Appliances and Lighting (EEDAL) conference, London, June 2006

[23] A. Almeida, P. Fonseca, B. Schlomann, N. Feilberg, C. Ferreira. Residential Monitoring to Decrease Energy Use and Carbon Emissions in Europe, Energy Efficiency in Domestic Appliances and Lighting (EEDAL) conference, London, June 2006

[24] Standby product profile 2004/15: Burglar alarms. The National Appliance and Equipment Energy Efficiency Committee, Australia., www.energyrating.gov.au, 2006

[25] ENERTECH. Demand-side management End-use metering campaign in 400 households of the European Community: Assessment of the Potential Electricity Savings, European Community SAVE Programme, Project EURECO, Contract N 4.1031/98.267, 2002

[26] O. Sidler. Demand-Side Management End-Use Metering Campaign in the Residential Sector, European Community SAVE Programme, Contract N 4.1031/93.58, Final Report, 1995

[27] S. Firth. Raising efficiency in photovoltaic systems: high resolution monitoring and performance analysis. PhD thesis, De Montfort University, UK, 2006

[28] Domestic photovoltaic field trial: final technical report, report number ETSU S/P2/00305/00/00 and S/P2/00409/00/00, Building Research Establishment, Garston, Watford, UK, 2006

[29] Research Systems Inc (RSI), www.rsinc.com

[30] A. Wright, S. Firth. The nature of domestic electricity loads and effects of time averaging on statistics and on-site generation calculations, Applied Energy 84 (2007) 389-403 
[31] L. Marjanovic, M. Coleman, A. Wright and H. Bruhns. Appliances Taxonomy across both Domestic and Non-domestic Building Sectors, submitted to ASHRAE Transactions

[32] K. Lomas, T. Oreszczyn, D. Shipworth, A. Wright and A. Summerfield. Carbon Reduction in Buildings (CaRB) - Understanding the social and technical factors that influence energy use in UK buildings, RICS Annual Conference Cobra, London, 2006

[33] M. Stokes, T. Crosbie and S. Guy. Shedding light on domestic energy use: a cross discipline study of lighting homes, RICS Annual Conference Cobra, London, 2006 


\section{Figure captions}

Figure 1: Sample dwellings and photovoltaic systems at Site 1 (left) and Site 2 (right)

Figure 2: Schematic of the IDL application generic routines

Figure 3: Five-minutely recorded total power consumption values for a single house over the two year monitoring period. The grey line shows the average values for each five minute period.

Figure 4: Five-minutely total power consumption recorded over a sample day at a single dwelling

Figure 5: Monthly averages of continuous and standby power consumption for three sample houses at Site 1

Figure 6: Five-minutely total power consumption recorded between 01:00 and 04:00 for two sample dwellings, showing refrigeration cycling

Figure 7: Annual total consumption totals per appliance consumption group and dwelling for the first year of monitoring

Figure 8: Total consumption against appliance group consumption for all dwellings in the first year of monitoring 
Table 1: Appliance categories and typical appliance power

\begin{tabular}{|c|c|c|c|c|}
\hline Appliance category & Category description & Example appliances & $\begin{array}{l}\text { Typical in-use } \\
\text { power }(W)\end{array}$ & $\begin{array}{l}\text { Typical standby } \\
\text { power (W) }\end{array}$ \\
\hline \multirow[t]{3}{*}{ Continuous } & \multirow{3}{*}{$\begin{array}{l}\text { Continuously switched on and } \\
\text { constant power consumption }\end{array}$} & Clocks $^{1}$ & 2.5 & - \\
\hline & & Burglar alarms $^{2}$ & 5 & - \\
\hline & & Broadband modems $^{1}$ & 4 & - \\
\hline \multirow[t]{7}{*}{ Standby } & \multirow{7}{*}{$\begin{array}{l}\text { Actively switched on by } \\
\text { householders. When not in } \\
\text { use, power consumption may } \\
\text { be non-zero. }\end{array}$} & Televisions - CRT $^{1}$ & 84 & 3.5 \\
\hline & & Televisions - LCD ${ }^{1}$ & 130 & 2.0 \\
\hline & & Televisions - plasma $^{1}$ & 253 & 2.7 \\
\hline & & Set top boxes ${ }^{1}$ & 17 & 8.0 \\
\hline & & Audio $\mathrm{HiFi}^{1}$ & 14 & 8.2 \\
\hline & & Mobile phone chargers ${ }^{1}$ & 4 & 2.8 \\
\hline & & Desktop computer ${ }^{1}$ & 100 & 7.1 \\
\hline Cold & $\begin{array}{l}\text { Continuously switched on and } \\
\text { power consumption cycles } \\
\text { between zero and a set power } \\
\text { level }\end{array}$ & Fridges / freezers / fridge freezers ${ }^{3,4}$ & 80 to 250 & 8.8 \\
\hline \multirow[t]{6}{*}{ Active } & \multirow{6}{*}{$\begin{array}{l}\text { Actively switched on by } \\
\text { householders. When not in } \\
\text { use, power consumption is } \\
\text { zero. }\end{array}$} & Kettles & 2000 to 3000 & - \\
\hline & & Electric hobs $^{5}$ & 2500 & - \\
\hline & & Washing machine ${ }^{5}$ & 2000 & - \\
\hline & & Electric showers & 4000 to 9000 & - \\
\hline & & Lighting - CFL & 9 to 13 & - \\
\hline & & Lighting - incandescent & 60 to 100 & - \\
\hline
\end{tabular}

${ }^{1}$ figures from [23]

${ }^{2}$ figures from [24]

${ }^{3}$ figures from [25]

${ }^{4}$ figures from [26]

${ }^{5}$ figures from [19] 
Table 2: Site characteristics

\begin{tabular}{llllll}
\hline Site & $\begin{array}{l}\text { Number of } \\
\text { dwellings }\end{array}$ & Built form & Tenure & $\begin{array}{l}\text { Construction } \\
\text { date }\end{array}$ & Monitoring period \\
\hline 1 & 22 & Terrace bungalows & Social housing & 2001 & June 2002 to May 2004 \\
2 & 13 & Two-storey blocks and flats & Social housing & 2001 & February 2004 to January 2006 \\
3 & 12 & Flats (three-storey tower) & Social housing & 2003 & June 2004 to May 2006 \\
4 & 15 & Two-storey blocks & Social housing & 2002 & Nov 2004 to Oct 2006 \\
5 & 10 & $\begin{array}{l}\text { Two-storey detached and semi- } \\
\text { detached }\end{array}$ & Owner occupied & 2003 & Nov 2004 to Oct 2006 \\
\hline
\end{tabular}


Table 3: Annual consumption results for the first year of monitoring

\begin{tabular}{|c|c|c|c|c|c|c|c|c|}
\hline & \multicolumn{4}{|c|}{$\begin{array}{l}\text { Annual consumption of appliance categories } \\
\text { Mean (kWh); (as \% of household consumption) }\end{array}$} & \multicolumn{4}{|c|}{$\begin{array}{l}\text { Equivalent continuous power }{ }^{1} \\
\text { Mean (W) }\end{array}$} \\
\hline & Total & $\begin{array}{l}\text { Continuous } \\
\text { and } \\
\text { standby }\end{array}$ & $\begin{array}{l}\text { Cold } \\
\text { appliance }\end{array}$ & $\begin{array}{l}\text { Active } \\
\text { appliance }\end{array}$ & Total & $\begin{array}{l}\text { Continuous } \\
\text { and standby }\end{array}$ & $\begin{array}{l}\text { Cold } \\
\text { appliance }\end{array}$ & $\begin{array}{l}\text { Active } \\
\text { appliance }\end{array}$ \\
\hline All dwellings ( $\mathrm{n}=72$ ) & $\begin{array}{l}3100 \\
(100 \%)\end{array}$ & $601(19 \%)$ & $620(20 \%)$ & $1879(61 \%)$ & 354 & 69 & 71 & 215 \\
\hline $\begin{array}{l}\text { Low energy group } \\
(\mathrm{n}=24)\end{array}$ & $\begin{array}{l}1770 \\
(100 \%)\end{array}$ & 297 (17\%) & $535(30 \%)$ & 938 (53\%) & 202 & 34 & 61 & 107 \\
\hline $\begin{array}{l}\text { Medium energy } \\
\text { group }(n=24)\end{array}$ & $\begin{array}{l}2689 \\
(100 \%)\end{array}$ & 402 (15\%) & $577(21 \%)$ & $1710(64 \%)$ & 307 & 46 & 66 & 195 \\
\hline $\begin{array}{l}\text { High energy group } \\
(\mathrm{n}=24)\end{array}$ & $\begin{array}{l}4841 \\
(100 \%)\end{array}$ & $1104(23 \%)$ & 747 (15\%) & 2990 (62\%) & 553 & 126 & 85 & 341 \\
\hline
\end{tabular}

${ }^{1}$ Equivalent continuous power is the power consumption which, if it remained constant for a year, would consume an equivalent amount of energy as the annual consumption totals. 
Table 4: Electricity consumption statistics for all households (n=72)

\begin{tabular}{|c|c|c|c|c|c|c|c|c|}
\hline \multirow[t]{2}{*}{$\begin{array}{l}\text { Electricity } \\
\text { consumption } \\
\text { category }\end{array}$} & \multicolumn{2}{|c|}{$\begin{array}{l}\text { Annual electricity consumption } \\
\text { (kWh) } \\
\text { Mean (standard deviation) } \\
\text { Range: minimum to maximum }\end{array}$} & \multicolumn{6}{|c|}{ Paired samples t-test (Year 1 to Year 2 difference) } \\
\hline & Year 1 & Year 2 & $\begin{array}{l}\text { Mean } \\
\text { increase } \\
(\mathrm{kWh})\end{array}$ & $\begin{array}{l}\text { Mean } \\
\text { increase } \\
(\%)\end{array}$ & $\begin{array}{l}\text { 95\% confidence } \\
\text { interval (kWh): } \\
\text { lower to upper }\end{array}$ & t value & $\begin{array}{l}\text { significance } \\
\text { (2-tailed) }\end{array}$ & $\begin{array}{l}\text { significance } \\
\text { (1-tailed) }\end{array}$ \\
\hline $\begin{array}{l}\text { Total } \\
(\mathrm{n}=72)\end{array}$ & $\begin{array}{l}3100(1487) \\
902 \text { to } 7743\end{array}$ & $\begin{array}{l}3241 \text { (1668) } \\
920 \text { to } 8775\end{array}$ & 141 & 4.5 & -6 to 288 & 1.9 & 0.060 & 0.030 \\
\hline $\begin{array}{l}\text { Continuous } \\
\text { and standby } \\
(\mathrm{n}=24)\end{array}$ & $\begin{array}{l}601(634) \\
85 \text { to } 3375\end{array}$ & $\begin{array}{l}662(685) \\
74 \text { to } 3715\end{array}$ & 61 & 10.2 & -4 to 119 & 2.1 & 0.036 & 0.018 \\
\hline $\begin{array}{l}\text { Cold } \\
(\mathrm{n}=24)\end{array}$ & $\begin{array}{l}620(272) \\
118 \text { to } 1570\end{array}$ & $\begin{array}{l}610(270) \\
85 \text { to } 1464\end{array}$ & -9 & -1.5 & -40 to 21 & 0.6 & 0.538 & 0.269 \\
\hline $\begin{array}{l}\text { Active } \\
(\mathrm{n}=24)\end{array}$ & $\begin{array}{l}1879(1052) \\
333 \text { to } 5269\end{array}$ & $\begin{array}{l}1968 \text { (1132) } \\
383 \text { to } 5254\end{array}$ & 89 & 4.7 & -18 to 196 & 1.7 & 0.101 & 0.050 \\
\hline
\end{tabular}


Table 5: Electricity consumption statistics for all households by energy group

\begin{tabular}{|c|c|c|c|c|c|c|c|c|c|}
\hline \multirow[t]{2}{*}{$\begin{array}{l}\text { Electricity } \\
\text { consumption } \\
\text { category }\end{array}$} & \multirow[t]{2}{*}{$\begin{array}{l}\text { Energy } \\
\text { group }\end{array}$} & \multicolumn{2}{|c|}{$\begin{array}{l}\text { Annual electricity } \\
\text { consumption (kWh) } \\
\text { Mean (standard deviation) } \\
\text { Range: minimum to maximum }\end{array}$} & \multicolumn{6}{|c|}{ Paired samples t-test (Year 1 to Year 2 difference) } \\
\hline & & Year 1 & Year 2 & $\begin{array}{l}\text { Mean } \\
\text { increase } \\
(\mathrm{kWh})\end{array}$ & $\begin{array}{l}\text { Mean } \\
\text { increase } \\
(\%)\end{array}$ & $\begin{array}{l}95 \% \\
\text { confidence } \\
\text { interval } \\
\text { (kWh): lower } \\
\text { to upper }\end{array}$ & $\begin{array}{l}\mathrm{t} \\
\text { value }\end{array}$ & $\begin{array}{l}\text { significance } \\
\text { (2-tailed) }\end{array}$ & $\begin{array}{l}\text { significance } \\
\text { (1-tailed) }\end{array}$ \\
\hline \multirow{4}{*}{$\begin{array}{l}\text { Total } \\
\text { household } \\
(\mathrm{n}=72)\end{array}$} & Low & $1770(322)$ & $1964(554)$ & & & & & & \\
\hline & & 902 to 2160 & 920 to 3447 & 195 & 11.0 & 14 to 376 & 2.2 & 0.036 & 0.018 \\
\hline & Medium & $\begin{array}{l}2689 \text { (319) } \\
2174 \text { to } 3247\end{array}$ & $\begin{array}{l}2670 \text { (687) } \\
1195 \text { to } 4600\end{array}$ & -19 & -0.7 & -270 to 231 & -0.2 & 0.875 & 0.438 \\
\hline & High & $\begin{array}{l}4841 \text { (1198) } \\
3273 \text { to } 7743\end{array}$ & $\begin{array}{l}5088(1484) \\
2994 \text { to } 8775\end{array}$ & 247 & 5.1 & -87 to 582 & 1.5 & 0.140 & 0.070 \\
\hline \multirow{4}{*}{$\begin{array}{l}\text { Continuous } \\
\text { and standby } \\
(\mathrm{n}=24)\end{array}$} & Low & $297(271)$ & $375(232)$ & & & & & & \\
\hline & & 85 to 1265 & 74 to 1015 & 78 & 26.3 & -23 to 179 & 1.6 & 0.122 & 0.061 \\
\hline & Medium & $\begin{array}{l}402(234) \\
117 \text { to } 1054\end{array}$ & $\begin{array}{l}389(167) \\
140 \text { to } 814\end{array}$ & -13 & -3.1 & -67 to 41 & -0.5 & 0.631 & 0.316 \\
\hline & High & $\begin{array}{l}1104(843) \\
90 \text { to } 3375\end{array}$ & $\begin{array}{l}1222(936) \\
114 \text { to } 3715\end{array}$ & 119 & 10.7 & -16 to 253 & 1.8 & 0.81 & 0.405 \\
\hline \multirow[t]{3}{*}{$\begin{array}{l}\text { Cold } \\
(\mathrm{n}=24)\end{array}$} & Low & $\begin{array}{l}535(273) \\
118 \text { to } 1137\end{array}$ & $\begin{array}{l}521(265) \\
85 \text { to } 1044\end{array}$ & -14 & -2.6 & -68 to 40 & -0.5 & 0.591 & 0.296 \\
\hline & Medium & $\begin{array}{l}577 \text { (203) } \\
313 \text { to } 975\end{array}$ & $\begin{array}{l}559(182) \\
279 \text { to } 1051\end{array}$ & -19 & -3.3 & -75 to 37 & -0.7 & 0.496 & 0.248 \\
\hline & High & $\begin{array}{l}747(295) \\
314 \text { to } 1570\end{array}$ & $\begin{array}{l}752(300) \\
324 \text { to } 1464\end{array}$ & 4 & 0.6 & -52 to 61 & 0.2 & 0.870 & 0.435 \\
\hline \multirow[t]{3}{*}{$\begin{array}{l}\text { Active } \\
(\mathrm{n}=24)\end{array}$} & Low & $\begin{array}{l}938 \text { (304) } \\
333 \text { to } 1495\end{array}$ & $\begin{array}{l}1069 \text { (445) } \\
383 \text { to } 2212\end{array}$ & 131 & 13.9 & 0 to 262 & 2.1 & 0.050 & 0.025 \\
\hline & Medium & $\begin{array}{l}1710(403) \\
952 \text { to } 2533\end{array}$ & $\begin{array}{l}1722(659) \\
548 \text { to } 3575\end{array}$ & 12 & 0.7 & -199 to 223 & 0.1 & 0.907 & 0.454 \\
\hline & High & $\begin{array}{l}2990 \text { (959) } \\
1661 \text { to } 5269\end{array}$ & $\begin{array}{l}3114 \text { (1024) } \\
1441 \text { to } 5254\end{array}$ & 124 & 4.2 & -100 to 348 & 1.1 & 0.264 & 0.132 \\
\hline
\end{tabular}



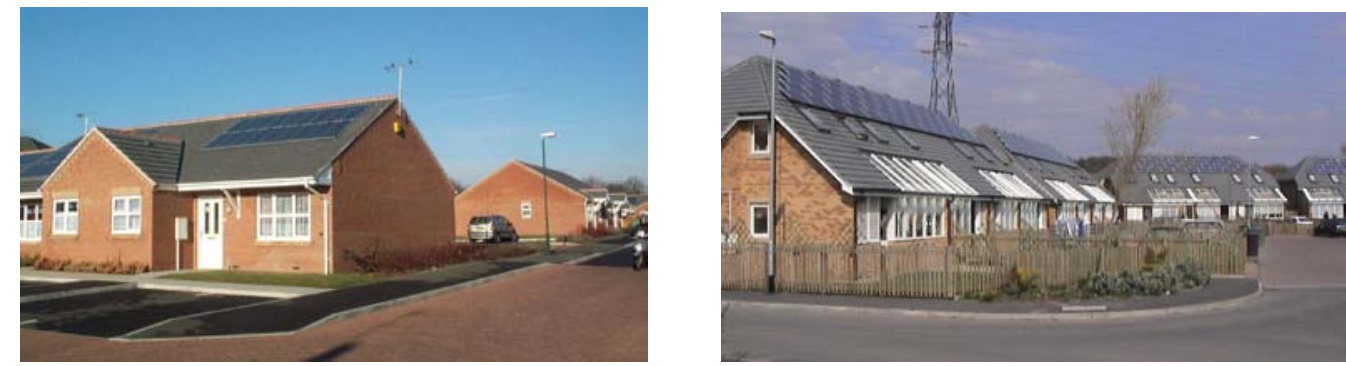

Figure 1: Sample dwellings and photovoltaic systems at Site 1 (left) and Site 2 (right) 


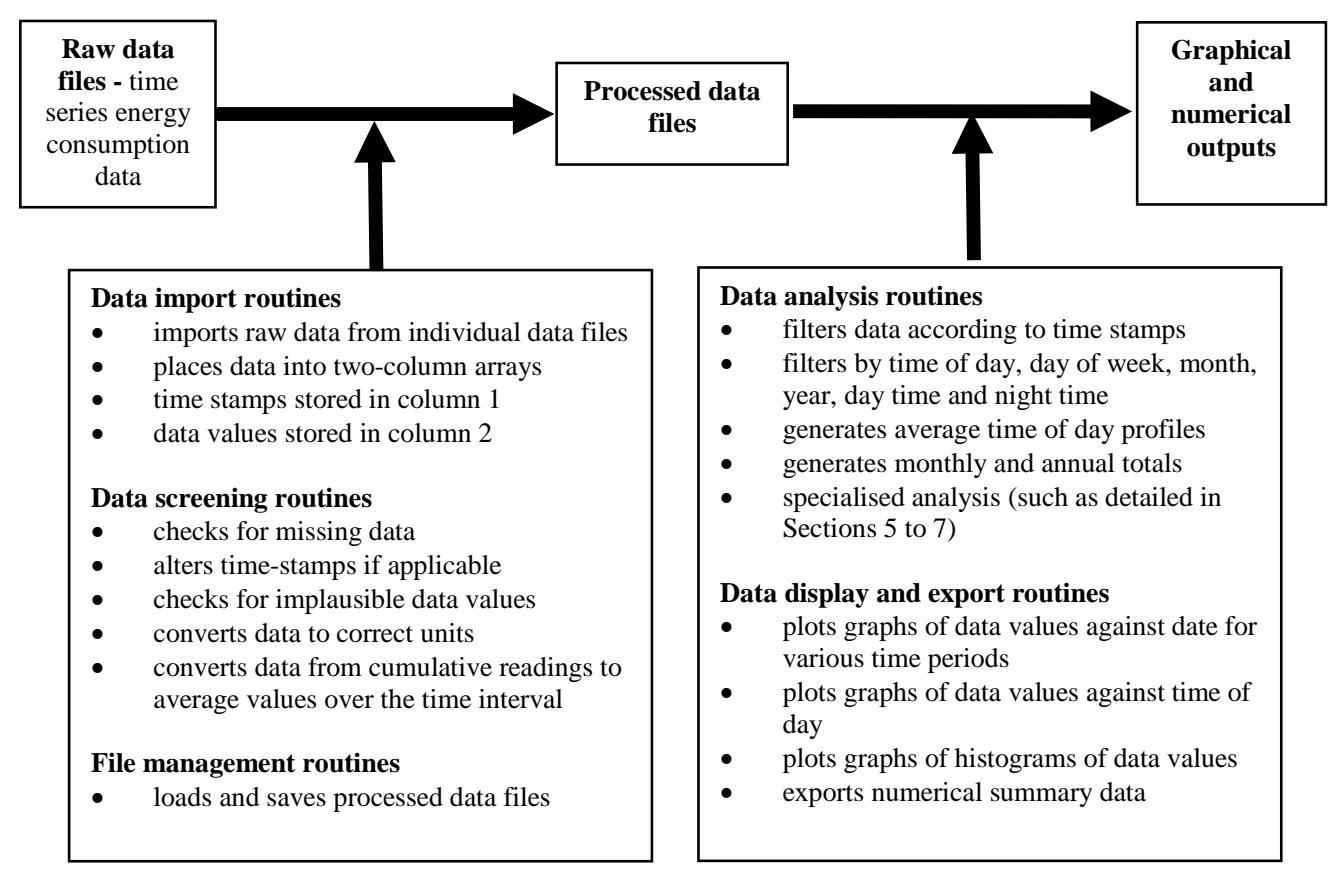

Figure 2: Schematic of the IDL application generic routines 


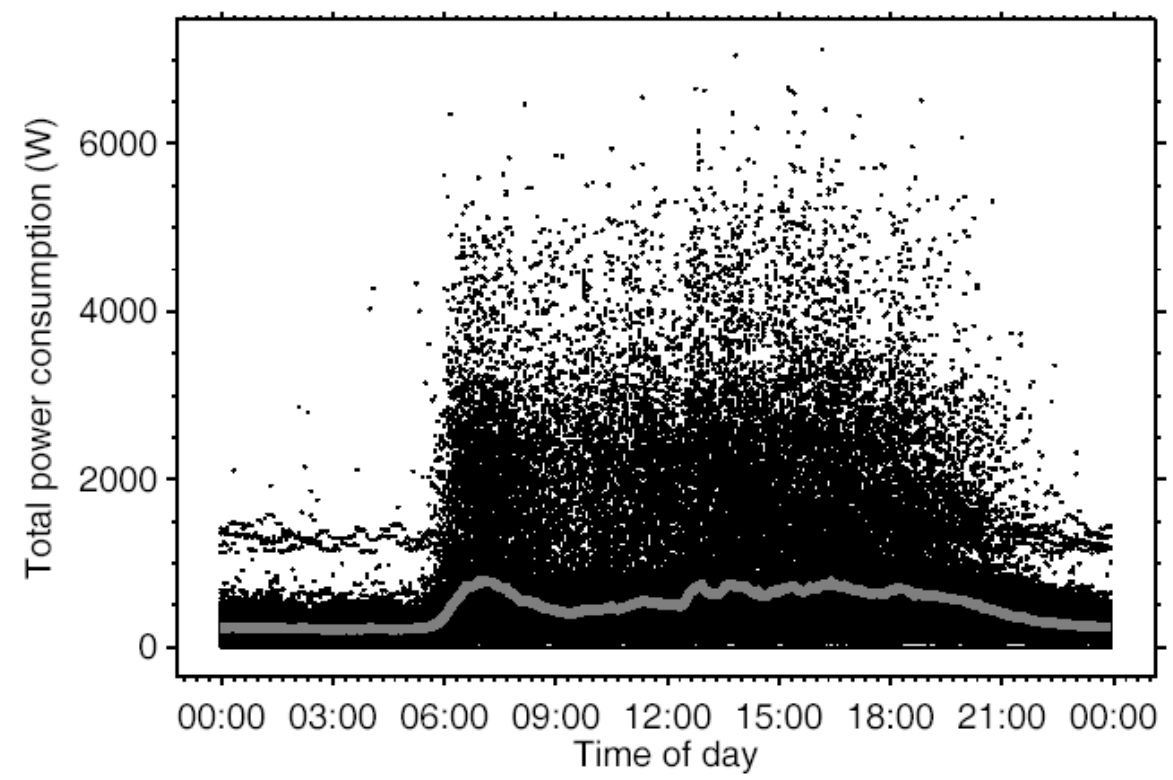

Figure 3: Five-minutely recorded total power consumption values for a single house over the two year monitoring period. The grey line shows the average values for each five minute period. 


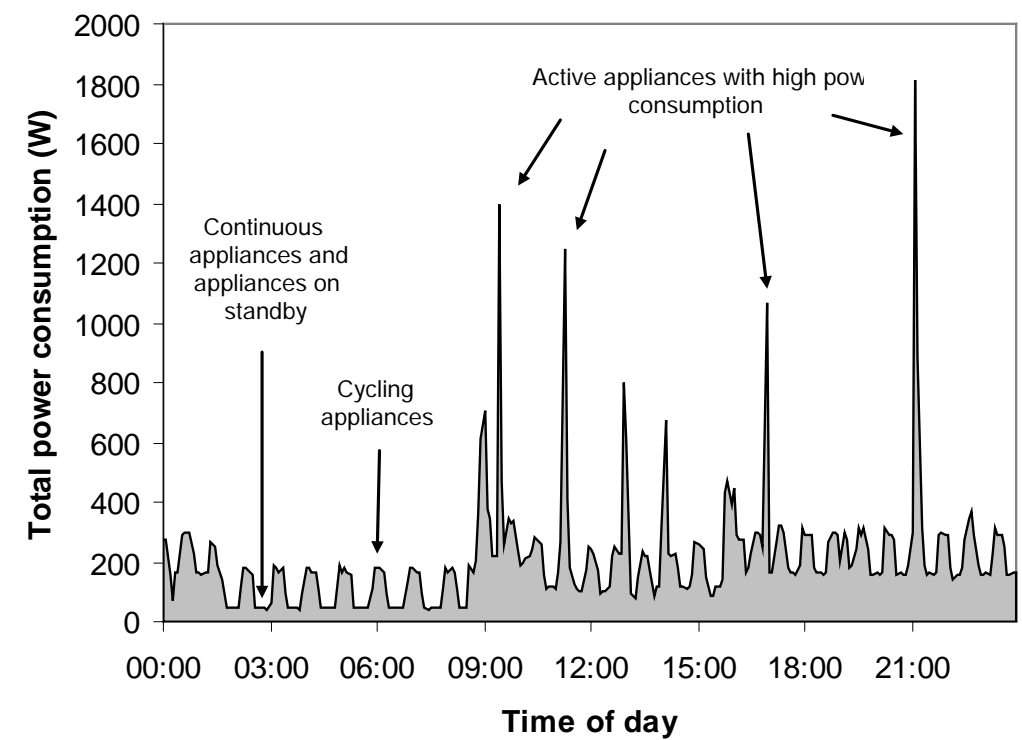

Figure 4: Five-minutely total power consumption recorded over a sample day at a single dwelling 


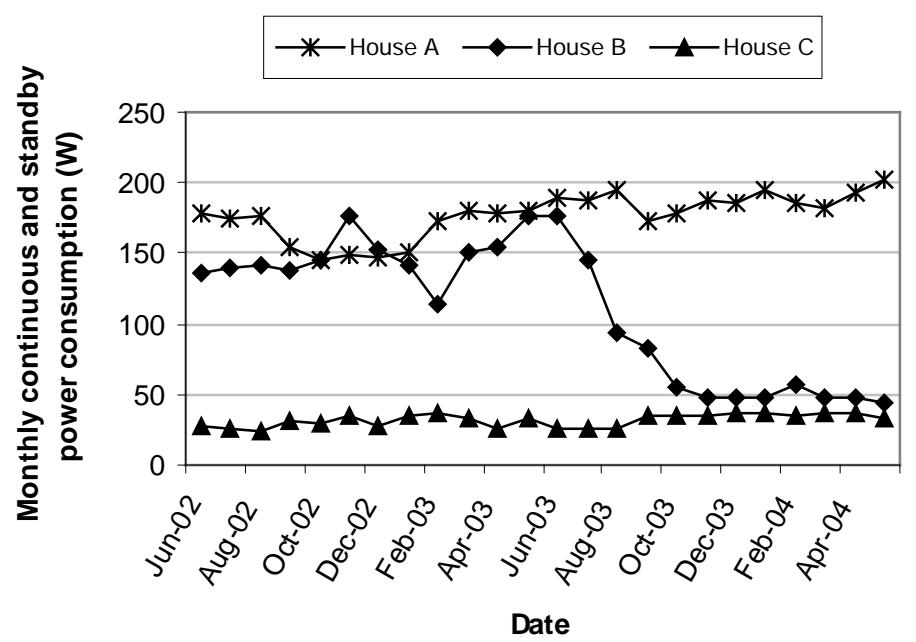

Figure 5: Monthly averages of continuous and standby power consumption for three sample houses at Site 1 


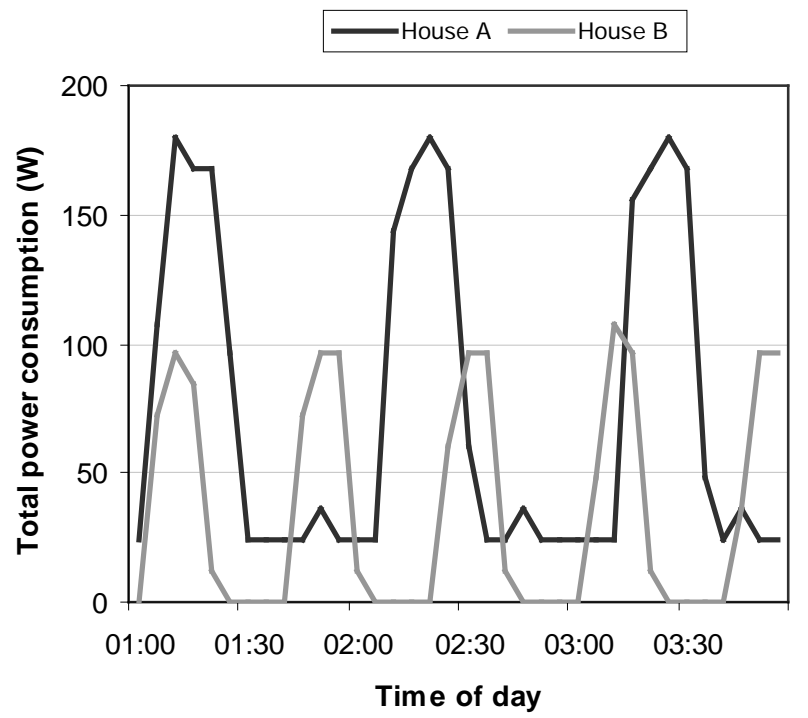

Figure 6: Five-minutely total power consumption recorded between 01:00 and 04:00 for two sample dwellings, showing refrigeration cycling 


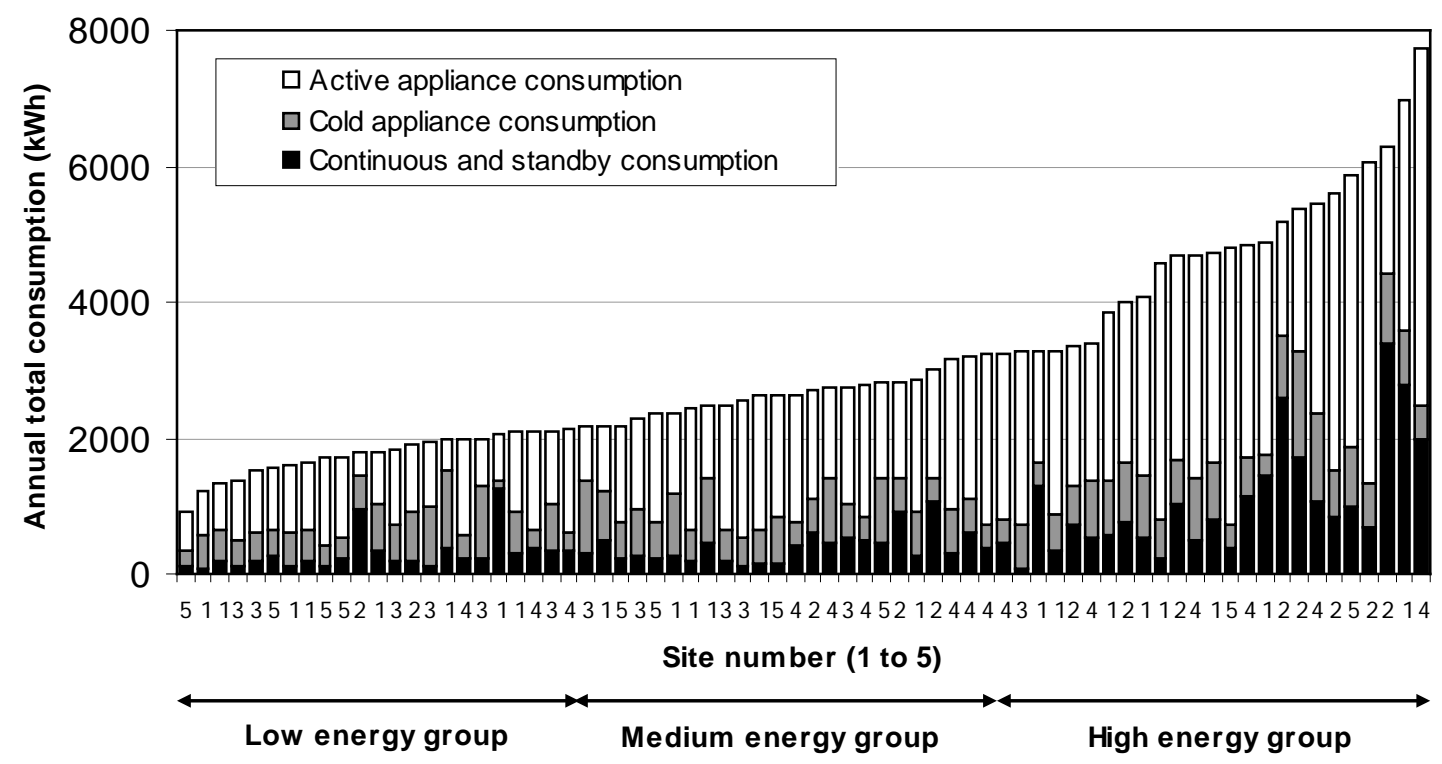

Figure 7: Annual total consumption totals per appliance consumption group and dwelling for the first year of monitoring 

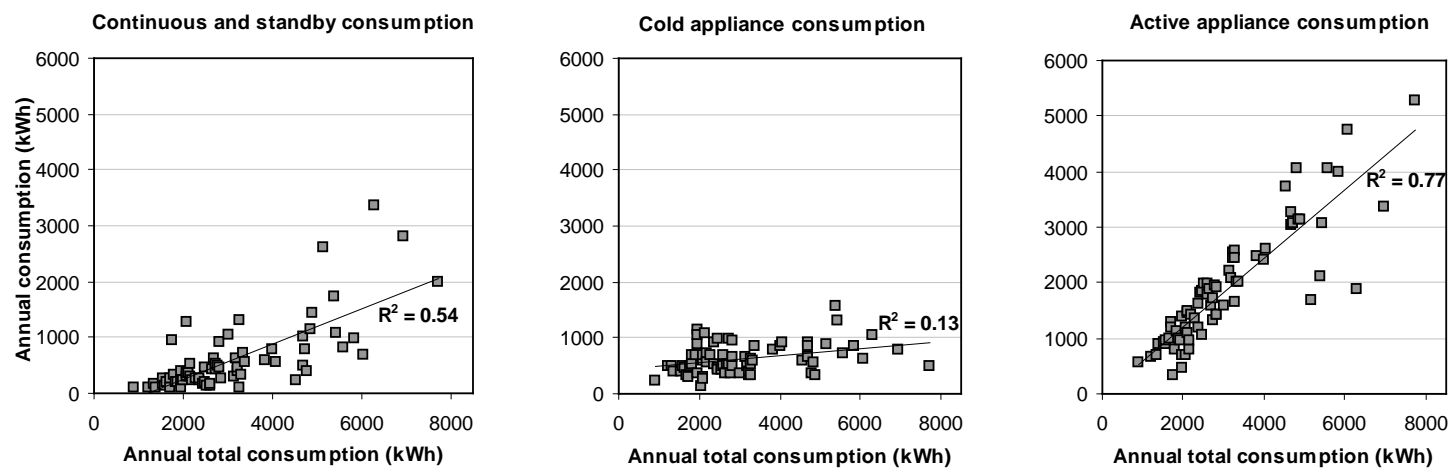

Figure 8: Total consumption against appliance group consumption for all dwellings in the first year of monitoring 